\title{
Television as total practices and liberalization of distinctions The Ukrainian case
}

\author{
Televisão como prática total e liberalização das distinções \\ O caso ucraniano
}

Natalia Kostenko*

\begin{abstract}
Abtract: The simultaneous effect of two opposite tendencies is peculiar to the Ukrainian television as well as to most national media. Firstly, communication assumes more and more universal character due to expansion of the access to the media and because of the standard content. At the same time cultural, social and political distinctions of communications free themselves as the result of the media market's influence. Both tendencies exhibit internal contradictions and counteractions. The obvious heterogeneity of viewer's preferences opposes the total entertainment effect of the media reality and essential resistant potential of the Ukrainian audience as well as low level of trust in political media oppose total control over political preferences of the viewers. It would seem that the articulation of distinctions corresponds to the real life styles of population, but in fact it turns out to be a fixation of the traditionally established division into cultural competent and undemanding audiences, a strengthening of "mechanical" pluralism sanctioned by media business. The situation with the Ukrainian media is considered on the basis of the results of sociological researches conducted by the Institute of sociology of National Academy of sciences of Ukraine in 2000-2007.
\end{abstract}

Keywords: Sociocultural differentiation of audience; Political media; Content analysis of TV news

Resumo: Os efeitos simultâneos de duas tendências opostas são peculiares à televisão ucraniana, bem como para a maioria dos meios de comunicação nacionais. Em primeiro lugar, a comunicação assume mais e mais caráter universal, devido à expansão do acesso aos meios de comunicação social e à padronização do conteúdo. Ao mesmo tempo, distinções de comunicação cultural, social e política se libertam como resultado da influência da mídia no mercado. Ambas as tendências apresentam contradições internas e ações contrárias. A óbvia heterogeneidade das preferências do telespectador opõe o efeito do entretenimento total da realidade da mídia e o potencial de resistência

* Head of Department of Culture and Mass Communication, Institute of Sociology, National Academy of Sciences of Ukraine, Kiev, Ukraine; e-mail: natalia.kostenko@gmail.com

\begin{tabular}{|l|l|l|l|l|l|}
\hline Civitas & Porto Alegre & v. 9 & n. 1 & p. 36-49 & jan.-abr. 2009 \\
\hline
\end{tabular}


do público ucraniano, assim como o baixo grau de confiança nas mídias políticas opõe controle total sobre as preferências dos telespectadores. Pareceria que a articulação de distinções corresponde ao verdadeiro estilo de vida da população, mas, na verdade, torna-se uma fixação da divisão tradicionalmente estabelecida entre públicos culturalmente competentes e não-demandantes, um reforço ao pluralismo "mecânico" estabelecido pela mídia empresarial. A situação da mídia ucraniana é considerada a partir dos resultados das pesquisas sociológicas realizadas pelo Instituto de Sociologia da Academia Nacional de Ciências da Ucrânia, entre 2000 e 2007.

Palavras-chave: Diferenciação sócio-cultural do público; Mídia política; Análise de conteúdo de Tv

The statements of sociologists concerning the influence of media on society and social communication have started including issues of problematical character, ambivalence and paradoxes. The situation in Ukraine is no exception, which is confirmed yet again by political campaigns of the recent years, presidential and parliamentary elections. But media are not only politics. Nowadays they actually install the legitimating of social ontology: "to be is to be shown on TV" (Bourdieu, 2002, p. 25) or to be present, to have one's place on the World Wide Web, which is true not only for celebrities but also for any events, phenomena, statuses and styles - past, present and future, global and local ones.

\section{Opportunities and barriers}

"Modern society approaches... a certain border beyond which nothing is uncommunicated, with the sole long-known exception - communication of sincerity" (Luhmann, 2005, p. 144). This statement of Niklas Luhmann is rather precise in pointing out indefinite opportunities and unbeatable barriers of media systems which are now able to construct discourses on any subject not claiming to be absolute authentic but nevertheless not producing disappointing musings over the old deficit problem. Media researchers and social sciences theoreticians have already announced how to understand media and what to expect from them. The general formula is brought down to the acknowledgement of articulation of meaning character of social system as the most important function of media (Luhmann, 2001, p. 13), i. e. of senses of interactions of people, structures and states.

Nowadays the permanently growing communication proposals from the old and the newest media can be actually realized only in part. At least two significant practical and conceptual problems stand in the way. Firstly, 
the selection of communications demands more and more actively special organization on mass and individual level and special regulation strategies and there will always be persons and institutions willing to take up this control. Secondly, the cultural anxiety over "sole reality" or so-called "objective reality" increases, with this reality losing self-evidence due to the attack of its numerous images in media and becoming more and more often the subject of "negotiations" and "agreements" striving to decide what is to be perceived as real (Willock, 2005). The first problem of communications choice makes topical the issue of publicity provided by media and in the end inspires political and management decisions. The second one returns us to the understanding of media communications nature.

As for this nature, despite great variety of approaches to studying media the majority agree that by covering the events mass media construct a special world image, and the society has accumulated a lot of diverse claims to such construction. The main reason for criticism is in the greatly enhanced capability of telecommunications to simulate reality, not only representing it but canceling any borders between simulation and representation. Strictly speaking, the media does not answer the well-known question "whether territory precedes the map or the map precedes the territory" (Baudrillard, 1983). The sensitivity to distinguishing such borders diminishes among mass audiences, and the media market builds new strategies and projects on this defect. As a result, the deeply rooted worries of respectable criticism concerning the cameras defining reality as a show for masses and an object for control by ruling elite are still valid. We speak about the influences of new technologies on the deterioration of public taste and the control over electorate which is especially topical for Ukraine that is permanently in the state of political elections. The objections against such fears are based on important statements protecting spectator satisfaction, freedom or choice and resistance to apologetics, and the end to these debates cannot be seen.

As in the most national media in Ukraine, two controversial tendencies are acting at the same time. 1) Communication gains a more universal character at the expense of better access to media and stereotypical content (only $6 \%$ of the Ukrainian population, who does not have a TV set, are not TV viewers, and the global culture imposes its standards in a more and more intensive way) (Kostenko, 2007a, p. 175). 2) At the same time, under the influence of media market cultural, social and political differences of communications are liberated. Both tendencies exhibit internal controversies and counteractions. The obvious heterogeneity of viewer's preferences opposes the total entertainment effect of the media reality and essential resistant potential of 
the Ukrainian audience as well as low level of trust in political media (at about $30 \%$ ) oppose total control over political preferences of the viewers (Panina, 2005 , p. 50). It would seem that the articulation of distinctions corresponds to the real life styles of population, but in fact it turns out to be a fixation of the traditionally established division into cultural competent and undemanding audiences, a strengthening of "mechanical" pluralism sanctioned by media business. This is how it looks like in empirical facts.

\section{Television control and social guardianship}

The situation in the field of media consumption does not exclude television control and social guardianship. According to the data of annual monitoring of Institute of Sociology "Ukrainian society", ${ }^{1}$ the sympathies of Ukrainian audiences to television genres are rather stable and conservative. Just as three years ago, $70 \%$ prefer fiction films, two thirds prefer the news (up to 66\%) and a half prefers entertainment and humoristic programs (up to $55 \%$ ). If something did change, it is the progressing appeal of local TV series on Russian and Ukrainian television (from 27\% to 34\%) and also that of "realistic" programs - documentaries (from 14\% to $28 \%$ ) and "real television" (from 7\% to 14\%). Both supply and demand for these television products are growing, which actually corresponds to global tendencies. At the same time, the attention towards programs pretending to analyze current situations - as informational and analytical and criminal programs - rather reduces (Kostenko, 2007b, p. 411).

Meanwhile, TV viewing preferences of citizens are actually differentiated according to habits and attitudes of spectator types (Figure1). Empirically, cluster analyses allow to determine seven such types, which include Minimalists (27\%), Empaths (19\%), Athletes (14\%), and Observers (11\%) located in the preferences zone of "simple" genres and constituting in total $3 / 4$ of adult audience, and also Analysts (13\%), Aesthetes (10\%) and Perfectionists $(6 \%)$, who prefer more "sophisticated" programs (Kostenko, 2007b, p. 412-415).

\footnotetext{
"Ukrainian Society" monitoring consists of annual sociological surveys conducted by the Institute of Sociology of the National Academy of Sciences of Ukraine since 1992. The sampling of each wave amounts to 1800 respondents on average and represents adult population of Ukraine (over 18 years of age). The survey results allow to observe and to analyze changes of social indices documenting the level of democratization of the Ukrainian society and the tendencies of socio-cultural development. The project is headed by V. Vorona, N. Panina, E. Golovakha (Panina, 2006, http://www.kar.net/ i-soc)
} 
Figure 1: Types of spectator preferences: 2007*

(\%, N=1800, monitoring "Ukrainian society")

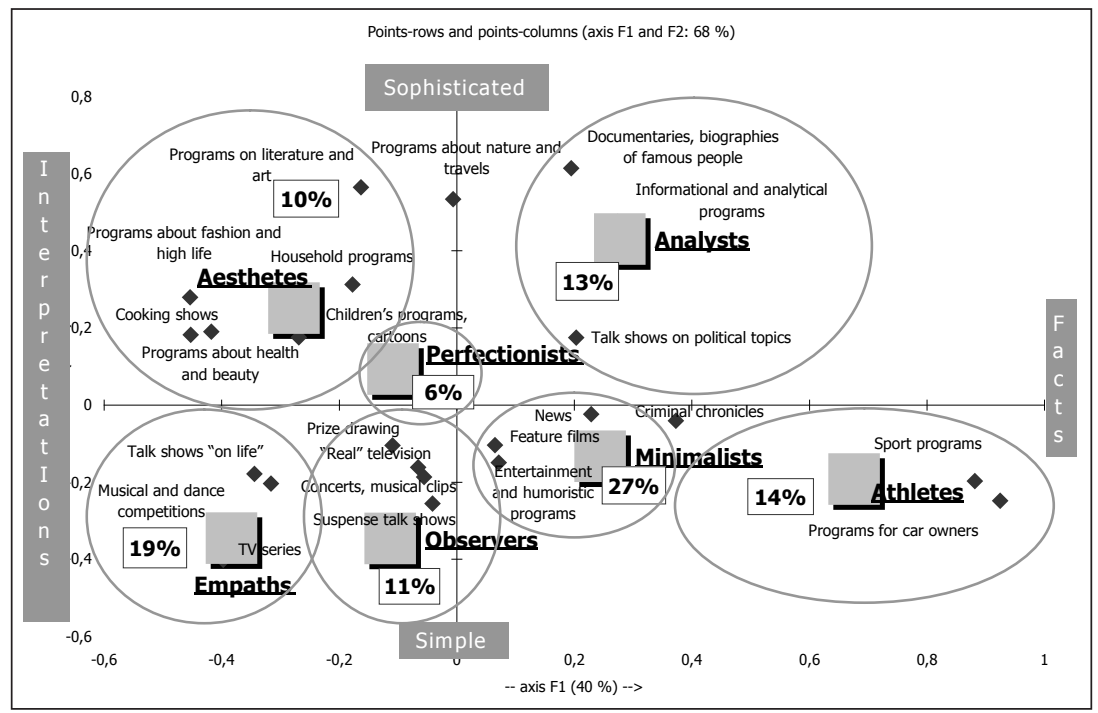

* Correspondence analysis, Chi-square, the level of significance alpha 0,050

In socio-cultural space, the types of $\mathrm{TV}$ program preferences are integrated into more generalized lifestyles, and their social geography is rather predictable in embodying intentions of traditional society and confirming explanations verified long ago (Figure 2):

1) the audiences on periphery are characterized by modest tastes and habitual or compensating consumption of television

2) competent middle-class public demonstrates an attitude for cultural consumption and possession of information

3) stable differentiation of "male-only" and "female-only" genres is supported both by peculiarities of their perceptions and the norms of femininity and masculinity cultivated in society.

Such evident articulation of cultural differences on television seems to fully correspond to the idea of variety. But it is no less agreed with the practices of directed social herding by, for instance, extension of space for the so-called trash genres providing to modest audiences "simple solutions to difficult problems", testing the boundaries of acceptable behavior and guarding marginal groups by providing a platform for talks about themselves (Grindstaff, 2005). By the way, this genre also includes the mutated example 
of political advertising, which has gained some popularity lately in Ukraine anti-advertising checking the borders of public discourse and political culture of society. No doubt, by combining reality and imitation and turning news into entertainment resource and vice versa, television averages our tastes and pretensions. But at the same time it follows the imperatives of media market and carefully segments the audience into target groups which should be enclosed and protected for a precise hit. In this way the traditional cultural inequalities are reproduced and made legitimate: "empty" or "easy" genres stay a product for socially weak groups.

Figure 2: Styles of TV viewing in socio-cultural space: 2007 * (\%, N=1800, monitoring "Ukrainian society")

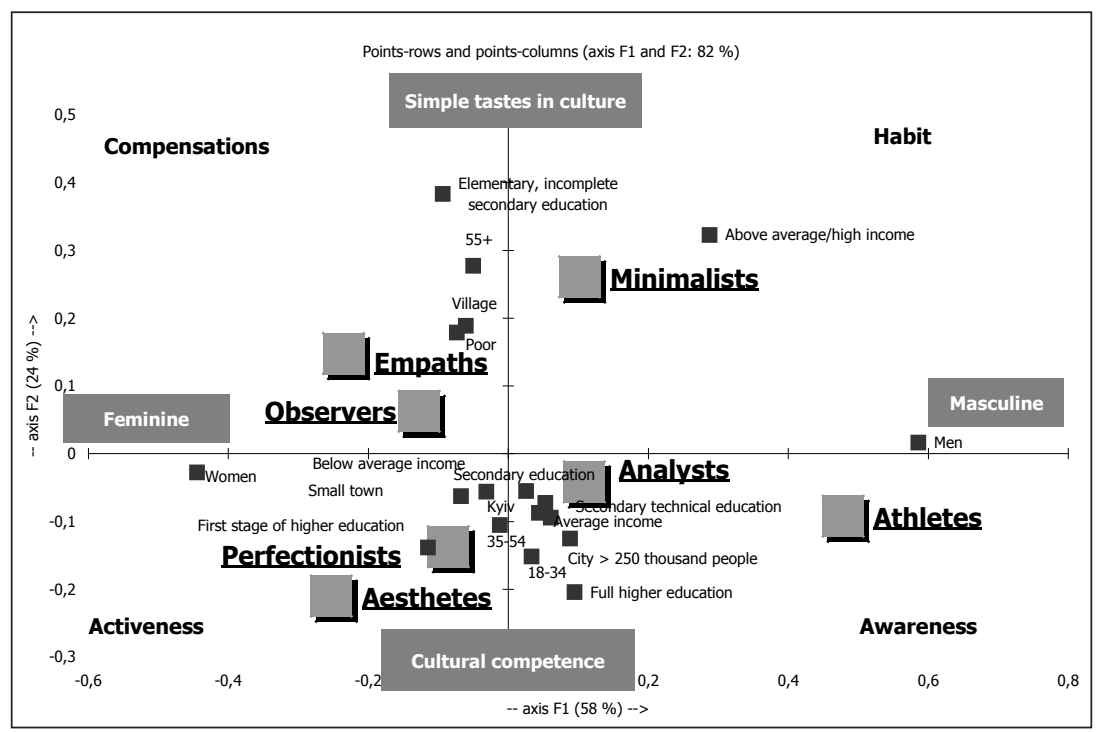

* Correspondence analysis, Chi-square, the level of significance alpha 0,050

\section{Political mobilization at the media market}

In the field of political communication, the tendencies of media to unify content and audiences at the same time articulating political distinctions are especially evident during pre-election campaigns when television news turn into a ring of symbolic struggle for the benevolence of the electorate. In Ukraine, the news are regularly viewed by two thirds of adult population and 
their political effect could have been significant but for the habitual attitude of Ukrainian audience to perceive media as a tool of influence from elite and acting authorities. According to the monitoring of "Ukrainian society" mentioned above media was always trusted less than the church and the army but more than the president, the government and political parties (Panina, 2005, p. 50). And the public has all reasons to believe this way as in TV news programs the field of Ukrainian politics is represented with significant deformations. Being a compromise among the influences of different controlling institutions - authorities, market, cultural and professional norms - the news will always stay interpretations of events which are presented in media as the events themselves. And the loyalty of such interpretations is usually directed to the side of the most influential political players. It is confirmed by the data of "Monitoring of political news" based on their content analysis and conducted since 2003 by the Ukrainian Press Academy together with the Institute of Sociology of the National Academy of Sciences of Ukraine ${ }^{2}$ (News vs. News, 2005).

Let us call the unifying practice of news "a privilege of the strong". As long-term observations show, the attention to different actors of politics is a certain and little changing value in TV news. On average, the attention to political institutions is present in $3 / 4$ of all messages about Ukraine, the attention to political personalities - in $2 / 3$ of messages, the attention to political

2 "Monitoring of political news" has been periodically conducted by Ukrainian Press Academy together with the Institute of Sociology of the National Academy of Sciences of Ukraine since 2003. The goal of research is to define the state and the dynamics of political content of the news on Ukrainian TV channels and the specifics of political advertising on television. The sample includes principal evening news programs on ten leading Ukrainian channels. The time frame of research is the first full week of each month. The sampling for each wave amounts to about 60 news programs ( 800 messages/90,000 seconds). The method used is content analysis of audiovisual information, it is conducted by trained operators according to a specially developed program (method reliability coefficient equals to $85-95 \%$ for different analysis categories).

The main indices documented: 1) degree of balance in events interpretation (percentage of messages with only one/several viewpoints of the event in the general mass of messages); 2) rating of attention to political actors/estimates of political actors (percentage of messages containing the names of political actors - institutions, political parties, persons/percentage of messages with positive, neutral, ironic, and negative evaluations of political actors); 3) access of politicians to news air (the volume of politician's "direct speech" - time of speaking on air in seconds, percentage from the total volume of politicians" "direct speech"); 4) types of news communication (documented empirically with the help of correspondence analysis depending on the degree of TV channels conjugation with the frequency of mentioning political actors, $\chi^{2}$ ). Additional indices in content analysis political advertising include: advertising type (percentage with explicit/implicit advertising of political actors), share of anti-advertising (percentage of messages containing anti-advertising), images of political forces leaders (percentage of advertising messages mentioning leader's qualities), social and political values in advertising (percentage of advertising messages mentioning values). The project is headed by N. Kostenko, V. Ivanov (News vs. News., 2005, http://www.aup.com.ua) 
parties - in $1 / 3$ of the news, i.e. "big politics" represented by the news is the politics of institutions and personalities while the presence of civic society structures in it is far less expressive (Kostenko, Ivanov, Makeyev, 2007, p. 72). Little is said about the choice among different ideologies or ways of country development. The attention of news towards the political platforms of parties and blocs is low even during the pre-election campaign (before extraordinary parliamentary election in September 2007 the political platforms were present in $8 \%$ of all news about Ukraine, and in August 2007 in $4 \%$ of all news) (Kostenko, Ivanov, Makeyev, 2007, p. 77).

At the same time, the so-called "bonus of power", i.e. increased attention to the first persons at the wheel is usually rather high, especially in the respect of president. Before the parliamentary elections of 2007 the popularity of President Viktor Yushchenko in the news exceeded the attention to any other politician by several times ( $30 \%$ of all messages about Ukraine) just as in December 2005 - March 2006 and can be compared with news popularity of President Leonid Kuchma in October 2003 - May 2004 not long before presidential elections (23\%) and also of Prime Minister Viktor Yanukovych in July - November 2004, i.e. during the period of presidential pre-election campaign (28\%). The rating of attention towards V. Yanukovych during the early parliamentary election in September 2007 amounted to 19\%, Aleksandr Moroz $-10 \%$, Yulia Timoshenko - 8\%, Vladimir Litvin - 3\%, that is, one can hardly speak about proportional representation of competing blocs leaders in the news (Kostenko, Ivanov, Makeyev, 2007, p. 82-84).

In general, the priority in attention rating during the whole pre-election campaign was on the side of pro-presidential bloc "Our Ukraine - People's Self-Defense" representatives (35-37\%). They were most often spoken of in the news practically on all leading Ukrainian TV channels, therefore stable unification of channel attention towards political forces is observed (Figure 3). We find another distribution in "direct speech", the air time of direct quotes from politicians, which is the index of real access of political forces to the news (Figure 4). The leader in the volume of direct speech during the whole campaign was the Party of Regions (leading party of majority coalition in the Parliament of that period) (32-26\%), which significantly overran other political forces ("Our Ukraine - People's Self-Defense" - 33\% in September 2007, Yulia Timoshenko Bloc - 13\%, Socialist Party of Ukraine - 13\%), while the share of "direct speech" for the leading party stayed the same every month of campaign (Kostenko, Ivanov, Makeyev, 2007, p. 91-96). Therefore, the model of "dual power" was implemented in the following way: OU-PS was more often spoken of, and the Party of Regions more often spoke itself. 
Figure 3: Distribution of attention to the representatives of political forces in the news: September 2007

( $N=1031$ mentionings about politicians, 604 messages , "Monitoring of political news")*

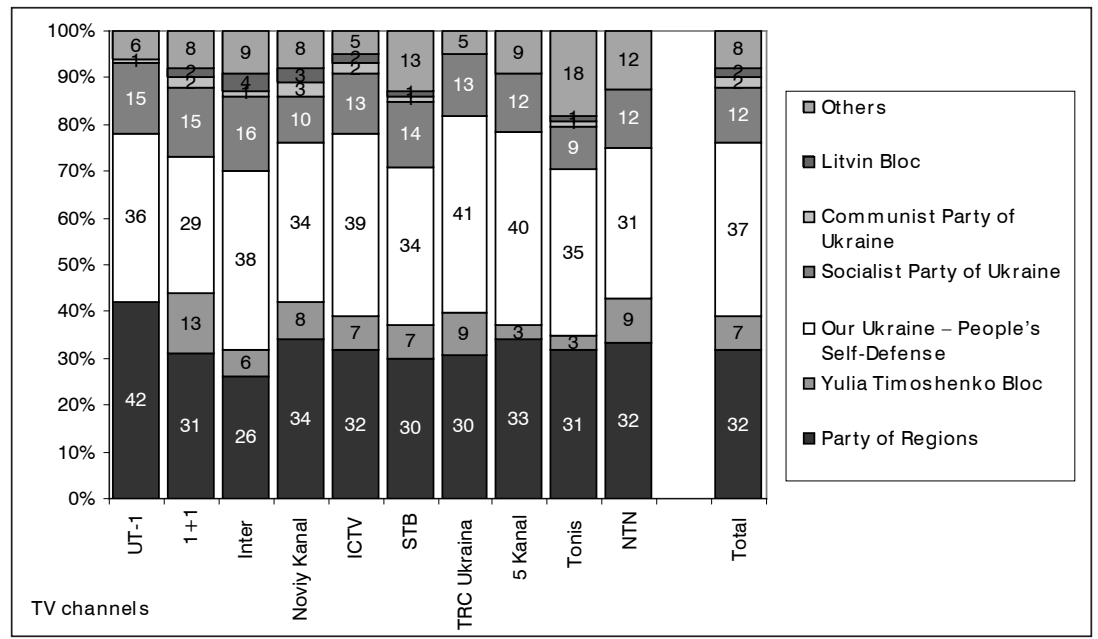

* Percentage $(\%)$ of attention to the representatives of a political force in the volume of attention to the representatives of all political forces

Figure 4: Distribution of air time ("direct speech") among the representatives of political forces in the news: September 2007

( $N=14004$ seconds, 604 messages, "Monitoring of political news")*

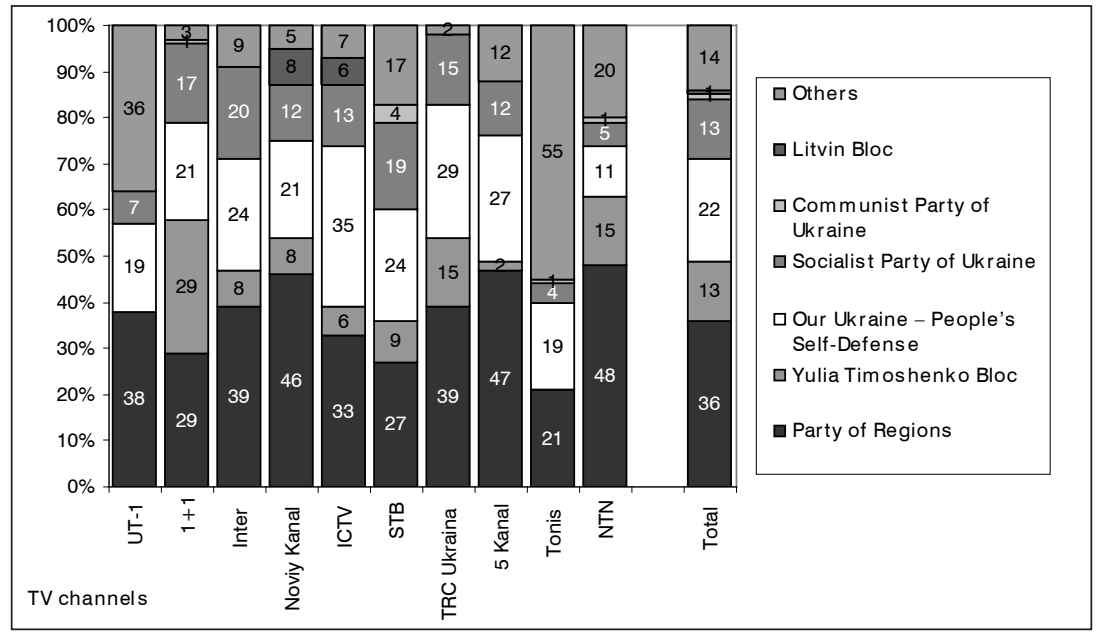

* Percentage (\%) of direct speech of political force representatives in the volume of direct speech of all political forces representatives 
If according to the rating of attention the channels mostly had standardized positions, they were very different in the case of "direct speech", and here the second tendency in news practices can be demonstrated, which is political mobilization on the media market. The differentiation is understandable as direct speech of a politician on air has a valuable price - time - and it cannot be given away thoughtlessly or accidentally. The results of news content analysis document the tendencies of channels belonging to different media holdings to unevenly distribute "direct speech" among the representatives of different political forces. In August 2007 Ukrainian channels TRC Ukraina, NTN and Inter did it in favor of the Party of Regions and the Communist Party of Ukraine, Noviy Kanal, ICTV, STB - in favor of "Our Ukraine - People's Self-Defense" and Socialist Party of Ukraine, 1+1 Channel most often gave word to Litvin Bloc and representatives of Yulia Timoshenko Bloc (as ICTV channel), UT-1 and Tonis - to the representatives of small parties, 5 Kanalto the majority of political forces (Figure 5) (Kostenko, Ivanov, Makeyev, 2007, p. 97).

Figure 5: Channel preferences in allocating air time to the representatives of different political forces: August 2007

( $N=552$ messages, 6897 seconds of direct speech , "Monitoring of political news")*

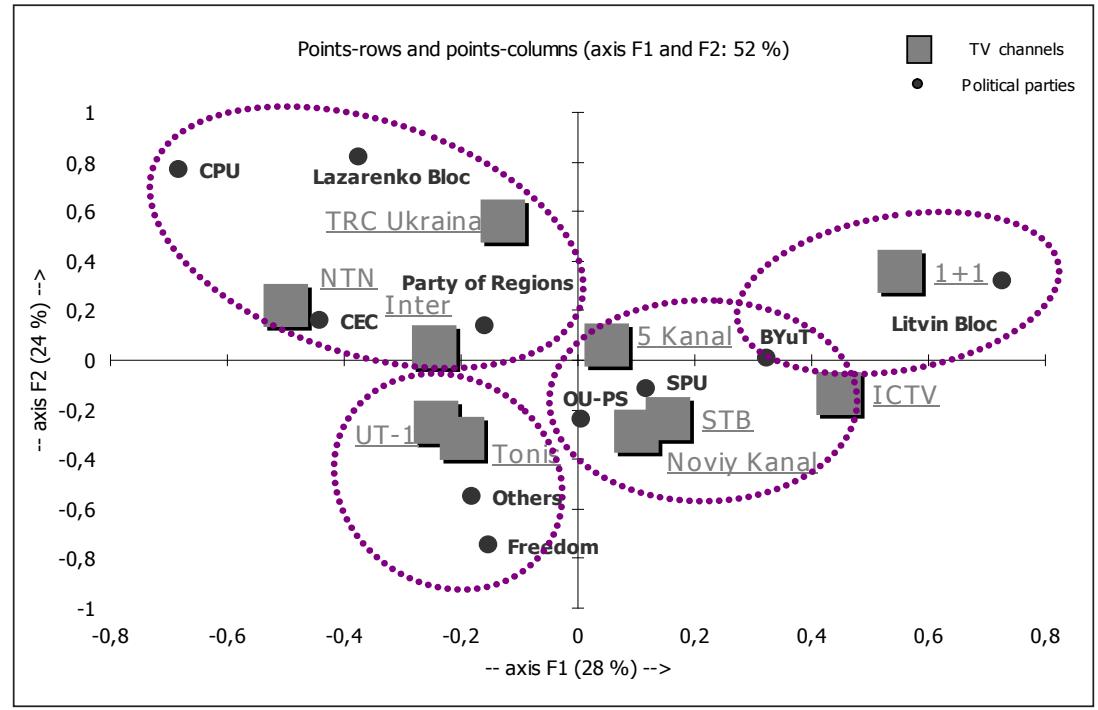

* Correspondence analysis, Chi-square, the level of significance alpha 0,050 
The cooperation of political elites and media business is demonstrated in pre-election advertising where it is cemented by no means symbolic capital but the strong financial interest. The main feature of advertising flow of the last parliamentary campaign is the unprecedented share of anti-advertising. If in March 2006 anti-advertising of candidates was in every tenth advertising message of television prime time (11\%) and occupied a half of air time allocated for advertising (49\%), in September 2007 it was respectively in every second message (47\%) or occupied $70 \%$ of advertising air time (Kostenko, Ivanov, Makeyev, 2007, p. 27-39).

It is not a secret that each influential political force in Ukraine has its own or sympathizing media resources. The space of media business is therefore combined with the politics space communicating general energy of the market and severe competition to the latter. Currently rather pluralistic image of media political content is created, but it is not as much due to liberal principles of independent press as according to the interests of owners. Therefore, we speak mostly of mechanical pluralism, which can be achieved by effectuating a complicated operation with news "puzzles".

The spectator is rather on the winning side but only in case he or she has the opportunity to watch news on all channels simultaneously. Those categories of citizens who got used to watch "their favorite channel" are hardly apt to do it. No doubt, this kind of plurality extends the horizons of politically possible. Nevertheless, two of its projections are well known. One of them, associated with sense strengthening of variety and distinctions, as a rule stays a desirable future. The other one, usually more real, promises to get rid of discomfort due to discrepancies of political commentaries in the media with the help of state mechanisms or wishes of owners to monopolize media space. Naturally, the state of political communication in Ukraine is more or less typical for transforming societies where it is most often not possible to create a fertile or at least an acceptable public discourse with the help of media (Pankov, Gochazh, 2004; Zorkaya, 2005). Ukrainian TV is not hurrying to present its own initiative in this aspect.

\section{Unexpressive alternative}

Internet is seen as an alternative to television; the use of the former becomes more and more popular among educated and young electorate. However, the paradox of the Internet as evident discrepancy between the idea of effective informational exchange, virtual democracy, direct cultural participation, all other known advantages of "informational society" and actually practiced stimulation of social inequalities is stable even in 
those European countries, which are significantly developed in this respect.

The Ukrainian example also possesses numerous inadequacies of media power and distortions of the public sphere. The interest of the Ukrainian audience in politics caused by extraordinary political events of the recent years is rather high in comparison with other transforming European countries and matches the interest in politics in the developed states. In Ukraine $64 \%$ of respondents are interested in politics, while there are $45 \%$ of those interested in Europe in total (Golovakha, Gorbachik, Panina, 2006, p. 11). Meanwhile, public communication is provided in Ukraine by the inclusion of population in the "old" media (television, radio and press) while the usage of new informational systems is still unprecedentally low on the European scale. According to the data of European social survey of $2005^{3}$ in developed Scandinavian countries Internet is used by more than two thirds of adult audience, in former socialist countries this number amounts to one third, and in the countries of European south it amounts to one fifth. Ukraine, where only one tenth of citizens use the Internet, does not join to general European picture, and even the elite cannot be viewed as a leader of electronic competence (Kostenko, 2007a, p. 183-188).

In Ukraine even the youth has the lowest indices of Internet use (Figure 6). While in Slovakia and Hungary a half, and in Poland and Slovakia a third of the youth can be considered its regular users, $80 \%$ of Ukrainian audience under 30 are practically isolated from the alternative information system and become vulnerable for the influence of more unified and stereotyped information of TV and radio channels (Kostenko, 2007a, p. 189). Similar disproportions point to strong dependence of transformational processes in Ukraine on initial conditions in comparison with post-socialist countries when relatively inexpressive differences in starting position may bring significant discrepancies in results. In modern chaos theories such dependence has a beautiful name of "butterfly effect", and if we apply it to Ukrainian society, this butterfly flapped its wings in the last century.

\footnotetext{
3 "European Social Survey" (ESS) is an all-European monitoring project with the participation of over 20 countries including Ukraine (since 2005). The project is headed by Roger Jowell. In Ukraine, the survey was conducted according to national random sample (2000 respondents surveyed) in March and April 2005 by the Institute of Sociology of the National Academy of Sciences of Ukraine and was directed by E. Golovakha, A. Gorbachik and N. Panina (Golovakha, Gorbachik, Panina, 2007, Ukrainian Society in a European Dimension, 2007, http://www.europeansocialsurvey.org)
} 
Figure 6: Internet usage in post-socialist countries among the youth aged 18-29: 2005

$(\%, E S S)$

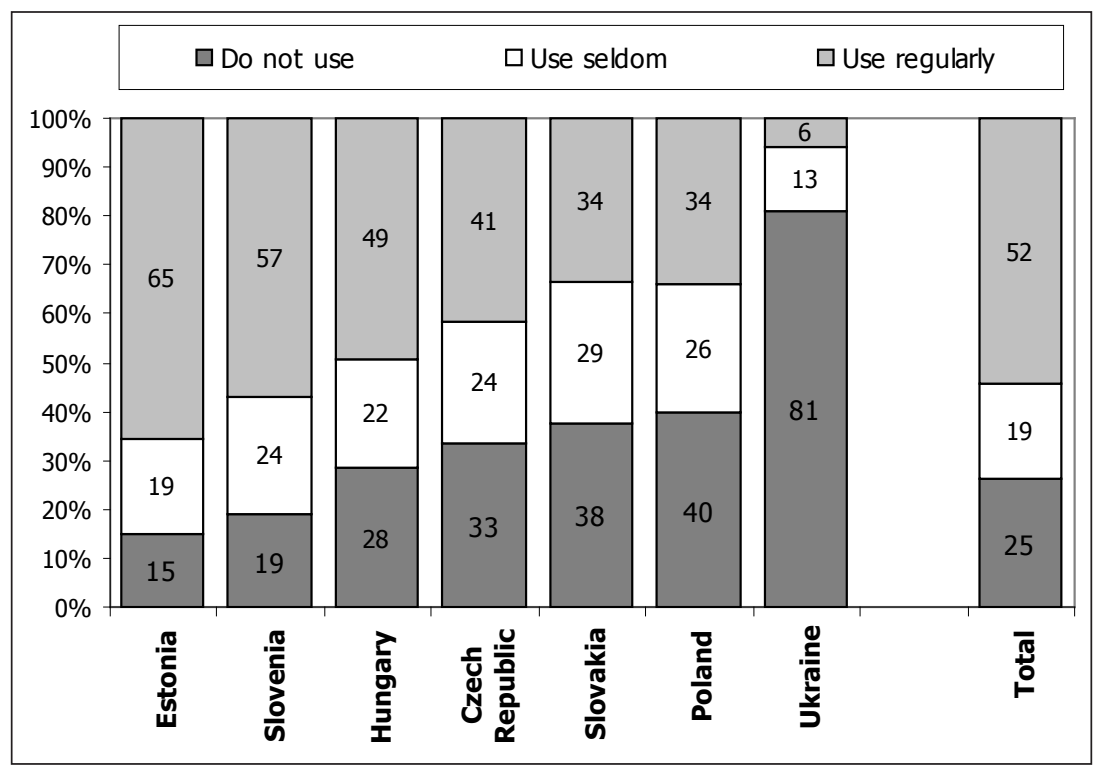

\section{References}

BAUDRILLARD, Jean. Simulations. New York: Semitotext(s), 1983.

BOURDIEU, Pierre. On television and journalism. Moscow: Scientific research fund "Culture pragmatics", Institute of experimental sociology, 2002 (Russian translation).

GOLOVAKHA, Eugene; GORBACHIK, Andrew; PANINA, Natalia. Ukraine and Europe: results of international comparative sociological research. Kyiv: Institute of Sociology, NAS of Ukraine, 2006.

GRINDSTAFF, Laura. "Real television" and politics of social control. In: Mass culture: modern Western research. Moscow: Culture pragmatics, p. 76-90, 2005 (Russian translation).

KOSTENKO, Natalia. National media audiences in comparison. In: Ukrainian society in a European dimension (Ed. by E. Golovakha, S. Makeev). Kiev: Institute of Sociology. NAS of Ukraine; Kharkov V. N. Karazin National University, p. 174-204, 2007 (in Russian). 
KOSTENKO, Natalia. Television between fact and interpretation. In: Ukrainian society 1992-1997. Dynamics of social changes (Ed. by V. Vorona, N. Shulga). Kyiv: Institute of Sociology, NAS of Ukraine, p. 409-422, 2007 (in Russian).

KOSTENKO, Natalia; IVANOV, Valery; MAKEYEV, Sergey. Political advertising and news on Ukrainian television during early parliamentary election of 2007. Kyiv: Ukrainian Press Academy, Institute of Sociology, NAS of Ukraine, 2007. http://www. aup.com.ua (in Ukrainian).

LUHMAMN, Niklas. Media communications. Moscow.: Logos, 2005 (Russian translation).

. Power. Moscow: Praksis, 2001 (Russian translation).

News vs. News. The election campaign in the TV news programs (Ed. by N. Kostenko. V. Ivanov). Kyiv: Institute of Sociology, NAS of Ukraine, Institute of Journalism of Kyiv University, Ukrainian Press Academy, 2005.

PANINA, Natalia. Ukrainian society 1992-2006: sociological monitoring. Kyiv: Institute of Sociology, NAS of Ukraine, 2006 (in Russian).

PANKOV, Vladimir; GOCIARZ, Vladislav. Consensus democracy and political market in Poland. In: Post-communist transformations: vectors, changes, dimensions, content. Kharkov: Kharkov National University Press, p. 328-353, 2004 (in Russian).

WILLOCK, David Everett. Reality as subject of negotiation: chaotic attractors of our understanding. In: Mass culture: modern Western research. Moscow: Culture pragmatics, p. 20-41, 2005 (Russian translation).

ZORKAYA, Natalia. Russian press: specifics of publicity. Journal of public opinion, v. 79, n. 5, 2005. http://www.levada.ru/zhurnal.html (in Russian). 